\title{
Parents And Jobs Of Parents With Student Achievements
}

\author{
Ferdiansyah Agung Saputra 1, Safruddin ${ }^{2}$, Edisonsiringoringo ${ }^{3}$ \\ S1 Nursing Study Program, Stikes Panrita Husada Bulukumba, Indonesia ${ }^{1}$ \\ Departemen Community and Family Nursing , Stikes Panrita Husada Bulukumba, Indonesia ${ }^{2}$ \\ Departemen Surgical Medical Nursing, Stikes Panrita Husada Bulukumba ,Indonesia ${ }^{3}$
}

Corresponding Autor : safaryahya1@gmail.com

\begin{abstract}
According to the World Health Organization (WHO) in 2015 had 42 million children who were overweight. This figure rose to 31 million from 2000. Obesity adolescents tend to have an impact on learning achievement and their health. The purpose of this study was students in senior high school 3 Bulukumba. 265 respondents sampling technique used consecutive sampling technique this type of research is an analytical study with a cross-sectional approach. The test used for the relationship of obesity whit student achievement is the fisher's exact test while the test used for the relationship of parental work with student achievement is the Kolmogorov Smirnov test. The results of the study are respondents with type 1 obesity with good achievement scores of 27 respondents (87.1\%) and achievement scores of less than 4 respondents (12.9\%). While respondents with type 2 obesity with good performance scores were 9 respondents $(56.2 \%)$ and achievement scores were less than 7 respondents. And the work of parents as PNS with a good achievement value of 15 respondents (93.8\%) and less achievement scores of 1 respondent $(1.6 \%)$. While respondents with the work of parents as entrepreneurs with good achievement scores of 10 respondents (55.6\%) and achievement scores of less than 8 respondents (44.4\%). Then the work of parents as farmers with good performance scores as many as 11 respondents. While the achievement score is less than 2 respondents (3.8\%). The conclusion of this study is there's is a relationship of obesity with the achievement of students in senior high school 3 Bulukumba between parental work and the achievement of students in high school 3 Bulukumba. As for the suggestion in this study can add library references and student insights on Sitekes Panrita Husada Bulukumba.
\end{abstract}

Keyword: Obesity, Parents Work, Achievement.

\section{INTRODUCTION}

Data from the World Health Organization (WHO) in 2015 there were 42 million overweight children, the figure is up 31 million from 2000, the WHO Global Nurition Report, (2016) shows that the number of children who are overweight will increase to 70 million soul in 2025 (Faridah \& Indriani, 2017). Meanwhile According to the Ministry of Health, (2010) shows the prevalence of obesity in Indonesia based on Body Mass Index (BMI) at the age of 6-12 years, namely, in boys by $10.7 \%$ and girls at $7.7 \%$. The incidence of obesity in children in the province of South Sulawesi is 6.4\%. While Riskesdas, (2013) shows BMI in children 6-12 years which is $9.2 \%$ or still above $5.0 \%$. And according to Riskesdas of the Province of South Sulawesi, (2007-2013) in the Regency of Bulukumba 


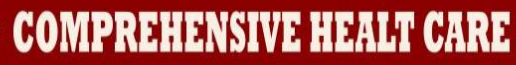

itself that is equal to (29.7\%) and ranks 12th in the Province of South Sulawesi. Se Sul-Sel District / City Health Office, (2015) Ministry of Education and Culture in 2017, showed data of 37,763 schools and in South Sulawesi province of 1,617 with a graduation rate of around 39,285. And in Bulukumba Regency especially the high school level, the average score of report card or achievement index is around 83.4 whereas in 2017 the average score of report card or achievement index is 71.61 .

The Disease Control and Prevention Agency of Bulukumba Regency recorded the number of obesity cases in 2016 as many as 913 cases. Based on data from the Bulukumba District Health Office from 10 sub-districts consisting of 20 puskesmas, 425 people from the Bonto Bahari Puskesmas (Bulukumba Health Office, 2016). According to Dewi, (2017) said that obese adolescents have lower academic achievement when compared to adolescents who are not obese. In obese children the average value is lower than students who have a normal weight and the average value is likely to decrease with increasing adolescent body weight. The impact of obesity on children causes an increase in blood pressure, cholesterol, arthritis, type II diabetes, bile heart disease, depressed asthma, anxiety and isolation from peers. So that the problem is not only in obesity, but how the physical and emotional consequences of obesity also have a negative impact on learning achievement in children in school, besides that mothers at tertiary education have obese children.

Previous research conducted by Dewi, (2017). The results showed there were differences in the average value of learning achievement between obese and non-obese students, the average value of learning achievement in obese students was lower when compared to non-obese students. And

The purpose of this study was to determine the relationship of obesity and parents' work with student achievement at SMA Negeri 3 Bulukumba in 2018.

\section{MATERIAL AND METHODS}

The research design or research design is also arranged so that the researcher can get an answer to the research statement (Setiadi, 2013). This type of research is an analytic study with a "cross sectional" approach where data concerning independent variables and dependent variables are collected at the same time (Notoatmodjo, 2012).

Population is a unit where a research result will be applied generalized Kusuma Darma, (2017). The population is the whole research subject that will be studied by Setiadi, (2013). The population in this study were all students of class II with a total of 


\section{COMPRABHENSWE HEAH CARE}

265. Sampling in this study was conducted by means of non-probability sampling that is sampling not random or nonrandom. By using consecutive sampling techniques, a sample selection method is done by selecting all individuals that are met and meet the selection criteria, until the desired number of samples is met (Kusuma Dharma, 2017). The sample in this study were 47 students from State High School 3 Bulukumba who were obese.

The research instrument for the obesity variable was an observation sheet using a digital scale and body meter / (Stature meter / Microtoice). Meanwhile, the instrument used for the achievement level variable is the observation sheet. Data were analyzed based on measuring scale and research objectives using computerized program software. Data were analyzed by: (1). Univariate Analysis, Analysis is done to see the proportion. (2). Bivariate Analysis, Bivariate test is carried out to find the relationship between the independent variable and the dependent variable with the test used is chi-square if it meets the requirements, and fisher's exact test will be conducted as an alternative if the main test is not met. The confidence interval taken was $95 \%$ and the accepted significance limit if $\mathrm{p}<0.05$.

\section{RESULTS}

Table 1.Distribution of Obesity Respondent Characteristics

\begin{tabular}{lcc}
\hline \multicolumn{1}{c}{ Characteristics } & n & Percentage (\%) \\
\hline Gender & 21 & 44.7 \\
Male & 26 & 55.3 \\
Girl & & \\
Age & 6 & 12.8 \\
15 years & 19 & 40.4 \\
16 years & 19 & 40.4 \\
17 years & 3 & 6.4 \\
18 years & 47 & 100.0 \\
\hline \multicolumn{2}{c}{ Amount } & 1) shows that the characteristics of respondents for the
\end{tabular}
characteristics of male sex are $22(44.7 \%)$ respondents with female sex are 26 (55.3\%) respondents. While the characteristics of the age of 16 and 17 years are at most 19 respondents (40.4\%) and the remaining 15 years are 6 respondents (12.8\%) and at 18 years are $3(6.4 \%)$ respondents.

Table 2.0besity1 and Obesity 2 Frequency Distribution Based on The IMT 


\section{COMPREABDSWE HEAH CARE}

\begin{tabular}{lcc}
\hline Obesity & n & $\begin{array}{c}\text { Percentage } \\
\text { (\%) }\end{array}$ \\
\hline Obesity 1 & 31 & 66.0 \\
Obesity 2 & 16 & 34.0 \\
Parents' job & & \\
Civil servants & 16 & 34.0 \\
entrepreneur & 18 & 38.3 \\
Farmers & 13 & 27.7 \\
Achievement Value & & 76.6 \\
Well & 36 & 23.4 \\
Less & 11 & 100.0 \\
\hline Amount & 47 & \\
\hline
\end{tabular}

Based on (Table 2) shows the frequency distribution shows that respondents who suffer from obesity 1 are 31 (66.0\%) more than respondents who suffer from obesity 2 which is 16 (34\%). And 18 (38.3\%) respondents who have self-employed parents are more than 16 (34.0\%) of parents as civil servants and 13 (27.7\%) of parents are farmers. And respondents with good achievement scores as many as 36 respondents $(76.6 \%)$ more than respondents with less achievement scores as many as 11 (23.4\%) respondents. Table 3. Distribution of Obesity Relationship with High School Student Achievement

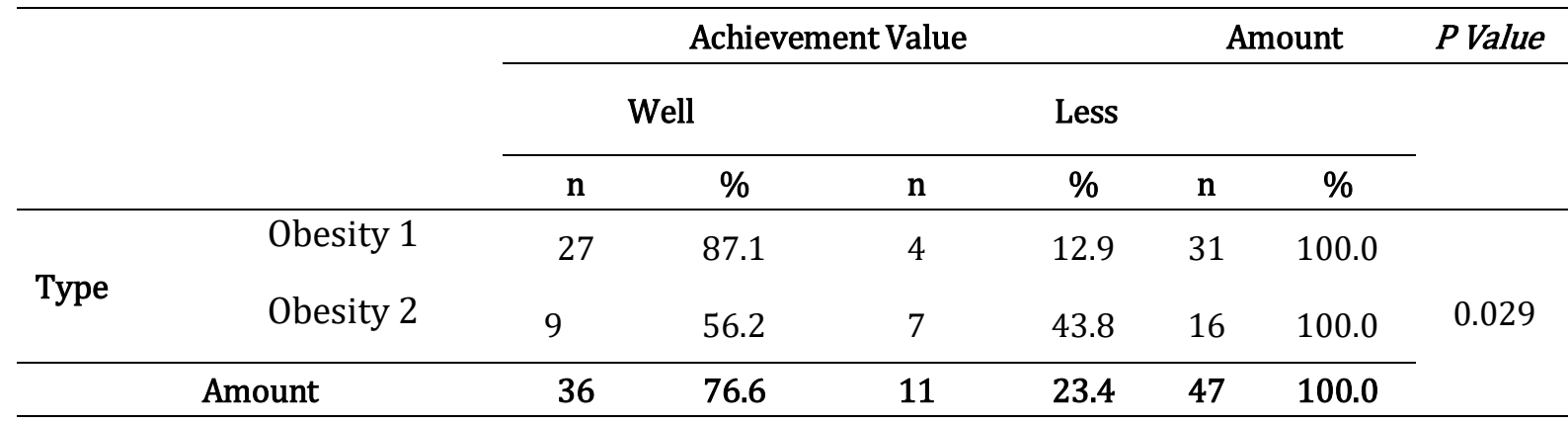

Based on (Table 3 ) shows the good achievement value of obesity type 1 as many as 27 respondents (87.1\%), and underachievement as much as $4(12.9 \%)$. And the good achievement score for type 2 obesity were 9 respondents (56.2\%) while the achievement score was less than 7 respondents (43.8\%). Based on the results of statistical tests using the chi-square test obtained ecpected count 1 cell $<5$ exceeds $20 \%$ and the main test requirements are not met, then alternative fisher exact test is used, and the p value is 0.029. So it can be concluded that there is a relationship of obesity with student achievement. 
Table 4. Distribution of Parents' Work Relationships with High School Student Achievement

\begin{tabular}{|c|c|c|c|c|c|c|c|c|}
\hline & & \multicolumn{4}{|c|}{ Achievement Value } & \multirow{2}{*}{\multicolumn{2}{|c|}{ Total }} & \multirow{3}{*}{$P$} \\
\hline & & \multicolumn{2}{|c|}{ Well } & \multicolumn{2}{|c|}{ Less } & & & \\
\hline & & $\mathrm{N}$ & $\%$ & $\mathrm{~N}$ & $\%$ & $\mathrm{~N}$ & $\%$ & \\
\hline \multirow{3}{*}{ Parents' job } & & 14 & 87.5 & 2 & 12.5 & 16 & 100.0 & \multirow{4}{*}{0.863} \\
\hline & entrepreneur & 11 & 61.1 & 7 & 38.9 & 16 & 100.0 & \\
\hline & Farmers & 11 & 84.6 & 2 & 15.4 & 13 & 100.0 & \\
\hline Amount & & 36 & 76.6 & 11 & 23.4 & 47 & 100.0 & \\
\hline
\end{tabular}

Based on (Table 4) respondents who have parents 'jobs as civil servants with good achievement scores of 14 respondents (87.5\%), and achievement scores less than 2 respondents (12.5\%), while respondents who have parents' jobs as entrepreneurs with good achievement scores as many as 11 (61.1\%) respondents, and underachievement scores as many as 7 (38.9\%) and respondents who have parents' work as farmers with good achievement scores as many as 11 respondents (84.6\%), compared with underachievement scores as much as 2 (15.4\%) respondent. Based on the results of statistical tests using the Kolmogorov Smirnov test, and the p value is 0.863 . So it can be concluded that there is no relationship between parents' work and student achievement.

\section{DISCUSSION}

In this study shows that there is a relationship of obesity with the achievements of high school students 3 Bulukumba. Based on the results of statistical tests conducted using the fisher's exact test, $\mathrm{p}$ values of 0.029 are less than $\alpha=(0.05)$. Then Ho is rejected and $\mathrm{Ha}$ is accepted. This proves that obesity is related to the achievement of Bulukumba 3 High School students. The results showed that, respondents with obesity type 1 with good achievement scores were 27 respondents (87.1\%) and underachievement scores were $4(12.9 \%)$ respondents. While respondents with the type of obesity 2 with good achievement scores were 9 respondents (56.2\%) and poor achievement scores were 7 (43.8\%). In line with Dewi's research results, (2017) Based on statistical test results p value $=0.00>0.005$, so it can be concluded that there are significant differences in the average value of subjects between non-obese and obese students.

Researchers assume that the cause of obesity is caused by the majority of students who eat more oily foods, eat more snacks and eat fast food at school that contains fat such as meatballs, fried foods and eat a large portion. This is because oily foods such as fried foods contain a lot of oils which are high in calories. When calories as a source of energy 
accumulate from what is needed, the body will store the excess as fat. The amount of accumulation of fat in the body causes excess weight. So it is said that obesity here affects student learning achievement because obese children will tend to be sleepy and easily tired so it is difficult to focus in terms of material acceptance when the teaching and learning process takes place so that it can have an impact on their achievement.

Based on the results of statistical tests using the Kolmogorov Smirnov test and the value of $p$ is 0.863 greater than $\alpha=(0.05)$. Then Ha is accepted and Ho is rejected. This shows the work of parents is not related to student achievement in SMA Negeri 3 Bulukumba. The results showed that respondents with a parent's job as a civil servant with a good value of preservation were 15 (93.8\%), compared to parents' job as a civil servant with less than 1 achievement (6.2\%) of respondents, while respondents with a parent's job as an entrepreneur with a good achievement score of 10 (55.6\%) compared to the work of parents as entrepreneurs with less achievement value of $8(44.4 \%)$ respondents. Then the parents' job as a farmer with a good achievement score of 11 (84.6\%) respondents, when compared to and the work of parents with less achievement value of 2 (3.8\%) respondents. So it can be concluded that there is no relationship between parents' work and student achievement in SMA Negeri 3 Bulukumba in 2018.

This is not in line with research conducted by Hardianto, (2014) there is a significant influence of parents' work on learning achievement. The work of parents affects the level of learning achievement. The researcher is of the opinion that respondents with parental employment as civil servants with good presenting values were 14 (87.5\%), and parental occupations as civil servants with underperformance scores were as much as $2(12.5 \%)$ respondents, while respondents with parental occupations as entrepreneurs with achievement values good as many as 11 (61.1\%) and work of parents with underachievement scores of 7 (38.9\%) brespondents. Then the work of parents as farmers with good achievement scores were 11 (84.6\%) respondents, and parents' jobs with poor achievement scores were 2 (15.4\%) respondents. Researchers assume that work is not the only thing that determines children's achievement. Ignoring many factors such as high motivation, and willingness to learn. In addition, this can also occur because the level of intellectual intelligence (IQ / intelligence quotient) students can also affect learning achievement.

\section{CONCLUSIONS}




\section{COMPRABHENSWE HEAH CARE}

Based on the above research results, it is concluded that there is a relationship of obesity with student achievement in SMA Negeri 3 Bulukumba in 2018. And there is no relationship between parents' work and student achievement at SMA Negeri 3 Bulukumba in 2018. The results of the research hopefully can increase knowledge for students at STIKES Panrita Husada Bulukumba. And for schools to further improve the quality of education in order to create cadres who excel and excel, and provide understanding to behave in healthy living, especially in children who are obese and at risk of obesity.

\section{REFERENCES}

Faridah, D., \& Indriani. (2017). Faktor Yang Berhubungan Dengan Overweight Dan Obesitas Pada Anak Usia Prasekolah Di TK "Aisyah Bustanul Athfal Kota Yogyakarta.

Riskesdas. (2013). Riset Keshatan Dasar. Jakarta: Badan Kesehatan RI Badan Penelitian dan Pengembangan Kesehatan.

Riskesdas Provinsi Sul-Sel. (2007-2013). Kementrian Kesehatan RI Badan Penelitian dan Pengebangan Kesehtan.

Dinas Kesehatan Kab/Kota Se Sul-Sel. (2015). Profil Kesehtan Provinsi Sulawesi Selatan.

Dinas Kesehatan Kabupaten. Bulukumba. (2014). Propil kesehata Kabupaten Bulukumba. Bulukumba: SIK.

Dewi, S. A. (2017). Perbedaan Prestasi Belajar Antara Siswa Obesitas Dan Tidak Obesitas Pada Siswa Sekolah Dasar Di Kota Kediri. Jurnal Ilmu Kesehatan.

Setiadi. (2013). Konsep dan Praktik Penulisan Riset Keperawatan Edisi II. Yogyakarta: Graha Ilmu.

Notoatmodjo, S. (2012). Metodologi Penelitian Kesehatan. Jakarta: Rineka Cipta.

Kusuma Darma, K. (2017). Metodologi penelitian Keperawatan. Jakarta: TIM.

Hardianto, H. (2014 ). Pengaruh Pendidkan, Pekerjaan Dan Pendapatan Orang Tua Terhadap Prestasi Belajar Ekonomi Pada Siswa Sma. Ekonomi Pendidikan Dan Kewirausahaan. Voleme 2.

Adam, D., Umboh, J., \& Warouh, S. (2015). Faktor Risiko Kejadian Obesitas Pada Remaja

Di Sma Negeri I Kabila Kabupaten Bone Bolango.

Ahmad, \& Syarifuddin. (2011). Penerapan model pembelajaran cooperative belajar dan faktor-faktor yang mempegaruhinya.

Black, J., \& Hokanson, J. H. (2014). Keperawatan Medikal Bedah. Singpore: Elsevier.

Gani, F. A., \& Maryam, S. (2015). Analisis hubungan status gizi dengan prestasi belajar remaja putri pada SMA negeri 1 kabupaten bireueng.

Ghullam Hamdu, \& Lisa Agustina. (2011). Pengaruh Motivasi Belajar Siswa Terhadap Prestasi Belajar Ipa Disekolah Dasar. Jurnal Penelitian Pendidikan.

Hamdu, G., \& Agustina, L. (2011). Pengaruh Motivasi Belajar Siswa Terhadap Prestasi Belajar Ipa Disekolah Dasar.

Hartini, K., Soetjiningsih, \& Nurani, N. (2014). Korelasi Derajat Obesitas Dengan Prestasi Belajar Siswa Sekolah Dasar. Seri Pediatri.

Heryanti, L., \& Satiawan, B. (2014). Kegemukan, Anemia,Dan Prestasi Belajar Siswa Sekolah Dasar Dikota Bogor. J Gizi Pangang. 


\section{COMPRABHENSWE HEAH CARE}

Labib, \& Sajawandi. (2015). Pengaruh Obesitas Pada Perkembagan Siswa Sekolah Dasar Dan Penangananya Dari Pihak Sekolah Dan Keluarga.

Muriyati, \& Syamsuddin . (2018). Dasar-Dasar Overweight Obesitas Aerobik . Babadan ponorogo Jawa Timur Indonesia: Wade Group.

Nurwati, E., Hadi, H., \& Julia, M. (2013). Paparan Iklan Junk Food Dan Pola Konsumsi Junk Food Sebagai. Jouernal Gizi Dan Dieteik Indonesia.

Riyani, y. (2012). Faktor-faktor yang Mempengaruhi Prestasi Belajar Mahasiswa. Jurnal EKSOS.

Sareharto, T. P., \& Sutrisno, M. T. (2015). Hubungan Inteligensi Dengan Prestasi Belajar Pada Anak Di Daerah Endemis Gaky. Media Medika Muda.

Sugiyono. (2017). Metode Penelitian Kuantitatif, Kualitatif dan R\& D. Bandung: ALFABETA.

Sujarweni, V. W. (2014). Metodologi Penelitian Keperawatan. Yogyakarta: Gava Media.

Susanto, A. (2013). Teori Belajar \& Pembelajaran Disekolah Dasar. JAKARTA.

Sutanto. (2010). Cegah dan Tangkal Penyakit Moderen (Hipertensi, Stoke, jantung, Kolesterol, dan Diabetes). Yogyakarta: ANDI.

Syamsuddin, Muriyati, Asnidar, \& Sumarmi. (2015). Pedoman Praktis Metodolo Penelitian Internal. Purwosari Babadan Ponogoro Indonesia: CV. Wade Group.

Tanto, C., Liwang, F., Hanifati, S., \& Pradipta, E. A. (2014). Kapita Selekta Kedokteran Jilid 1 edisi IV. Jakarta: Media Aesculapius.

Tazkya Amany, \& Rini Sekartini. (2015). Hubungan Antara Status Gizi Dengan Prestasi Belajar Siswa Sdn 03 Pondok Cina Depok tahun 2015. SARI PEDIATRI.

Vista, D., Delima E, R., \& Hutasoit, M. (2014). Status Gizi Tidak Signifikan Menentukan Prestasi Belajar Siswa SD. Media Ilmu Kesehatan.

Wulandini S, P., \& Mustika, D. (2017). Hubungan Status Gizi Dengan Prestasi Belajar Siswa Di Sdn 010 Pangkalan Kelinci Kabupaten Pelalawan. Menara Ilmu. 